research institutions with university faculties, and the development of new centres at universities.

The Committee proposes a ten-year plan costing 651 million dollars over and above the present level of expenditure. The plan is described as 'minimal' to meet long-range requirements, and it is stated that action on a scale appreciably less "will jeopardize the position of oceanography in the United States relative to the position of the science in other major nations, thereby accentuating serious military and political dangers, and placing the nation at a disadvantage in the future use of the resources of the sea".

The report has no official Government approval, but opinion in the United States expects it to guide the course of national support for marine science. Oceanographic research has already been earmarked by the President's Seience Advisory Committee as one of the major scientific fields needing more emphasis. Further afield it is also of interest. From its very nature, oceanography is dependent on, and contributes to, most of the other sciences; moreover, its pursuit involves international collaboration on an extensive scale. Any increased support in tho United States for oceanography will contribute to the development of the science and set an example which other countries might well follow.

\section{EARLY AMERICAN NATURALISTS}

\section{John and William Bartram's America}

Selections from the Writing of the Philadelphia Naturalists. Edited with an Introduction by Helen Gere Cruickshank. Pp. xxii +418 . (New York : The Devin-Adair Company, 1957.) 5 dollars.

The Travels of William Bartram

Edited with commentary and an annotated index by Francis Harper. Naturalist's edition. Pp. lxi +727 + 42 illustrations and facsimiles. (New Haven, Conn. Yale University Press; London : Oxford University Press, 1958.) 68s. net.

$\mathrm{T}$ HE Quakers John Bartram and his son William were two of America's leading naturalists throughout the eighteenth century-their combined lives cover a span of nearly one hundred and twentyfive years, from 1699 until 1823. Although they were primarily botanists, and John established the first botanic garden in America near Philadelphia about 1730 , they were widely interested in all aspects of natural history. In their early days there were few books that could help them in classifying the numerous undescribed species that they found, but when a merchant friend in Philadelphia took some of John's collections and observations to Peter Collinson of London, who immediately appreciated their value, a correspondence was started that lasted nearly fifty years. As a result of John's friendship with Collinson he entered into correspondence with nearly all the naturalists of Europe, including Linnæus and Sir Hans Sloane, and was elected into the fellowship of the Royal Society, and appointed "Botanist to His Majesty for the Floridas".

Both the Bartrams travelled extensively in pursuit of their studies, venturing far beyond the scattered settlements of the outposts into Indian territory where they endured many discomforts and hardships and not a few dangers. In 1743, John accompanied an expedition to make a treaty of peace with the Iroquois and travelled north to Oswego on the shores of Lake Ontario, but his major explorations were made twenty years later in Florida, a region which made a deep impression upon both him and his son. Afterwards, William also spent five years travelling through the Carolinas, Georgia, and Florida, gathering specimens and recording his observations. John was brought up to farming and had very little school ing; although he kept diaries of his travels he did not publish them and they were incorporated into the accounts printed by other members of his expeditions. William Bartram, however, had a fluent pen, and in 1791 he published at Philadelphia his "Travels through North and South Carolina, Georgia, East and West Florida", which was at once reprinted in London and Dublin, and translated into several foreign languages. This book, containing most interesting topographical, anthropological and biological observations, reveals him as a delightful character, full of curiosity, sympathy, and an appreciation of wild Nature rare in those days when the age of elegance regarded everything remote from the centres of civilization as a dreadful wilderness full of savage and horrid prospects.

The first of the volumes under review is an anthology of writings by, and about, the Bartrams, and is an excellent introduction for the general reader to the works of these pioneers. "Although William was one of the foremost of the earliest generation of American writers on natural history and travel, his work has never been known and appreciated in America the way it was abroad." There is no longer any reason for the prophet to be without honour in his own country. The second book is very much more ambitious. It is a reprint of the first edition of William's travels with a long and interesting introduction by Francis Harper, and a valuable commentary identifying the places visited, and the plants and animals seen, based upon extensive journeys made over Bartram's trails and upon much literary research. There is also a copious annotated index, an interesting section of illustrations and a number of maps. William Bartram's narrative is a fascinating account of America nearly two hundred years ago, and Harper's faithful editing enhances its lustre.

L. Harrison Matthews

\section{RUDIMENTARY GOVERNMENT}

\section{Tribes without Rulers}

Studies in African Segmentary Systems. Edited by John Middleton and [the late] David Tait. Pp. $x i+234$. (London: Routledge and Kegan Paul, Ltd., 1958.) 28s. net.

CEGMENTARY political systems constitute one of $\$$ two main types of indigenous political organization found in Africa. Unlike the centralized type, they have no forms of general tribal government. vested in chiefs or courts of law or any other overriding authority. They are made up of a collection of mutually independent segments, most commonly based on descent, which maintain law and order among themselves by various forms of self-help, including often the feud, and by making use of kinship, local and ritual bonds. Tribes of this type were, in the 'thirties, frequently recalcitrant to the 